\title{
The control of postoperative pain in elderly patients undergoing total hip replacement under spinal anesthesia
}

\author{
DM Mattiacci, ML Mingione, D Delle Donne, B Lettieri* \\ From XXIII Annual Meeting of the Italian Society of Geriatric Surgery \\ Lecce, Italy. 2-4 December 2010
}

\section{Background}

The hip replacement surgery is intended to reduce the intensity of joint pain and improve quality of life in patients with arthritic disease. Advanced age is not a limit to surgical treatment for subarachnoid anesthesia, which is well tolerated by elderly patients.

The aim of our study is to assess how spinal anesthesia with hyperbaric bupivacaine and buprenorphine and the subsequent use of an elastomeric pump can contribute to postoperative pain control in this type of surgery.

\section{Materials and methods}

We studied 42 patients (16M and 26F) ASA Class II and III. All patients underwent anesthesia sub arachnoid (needle 27G Whitacre, L3-L4, lateral decubitus), premedicated intravenously with $0.01 \mathrm{mg} / \mathrm{kg}$ of atropine, 2 mg midazolam, $500 \mathrm{ml} \mathrm{NaCl} 0.9 \%$ and monitored throughout the surgery. In group B $14 \mathrm{mg}$ of hyperbaric bupivacaine $0.5 \%(2.8 \mathrm{ml})$ was administered while in group B + B 0.5\% hyperbaric bupivacaine $12 \mathrm{mg}(2.4$ $\mathrm{ml}$ ) was added to $0.06 \mathrm{mg}$ buprenorphine $(0.2 \mathrm{ml})$.

Before the end of the intervention, we administered 30 $\mathrm{mg}$ of ketorolac, tramadol $100 \mathrm{mg}, 50 \mathrm{mg}$ of ranitidine, ondansetron $4 \mathrm{mg}$ in $100 \mathrm{ml}$ of $\mathrm{NaCl}$. Upon completion an elastomeric pump containing $60 \mathrm{mg}$ of ketorolac, tramadol $200 \mathrm{mg}, 100 \mathrm{mg}$ of ranitidine and ondansetron 4 $\mathrm{mg}$ (mixture of $60 \mathrm{ml}$ at $2 \mathrm{ml} / \mathrm{h}$ for a total of $30 \mathrm{~h}$ ) was applied to each patient. All patients were offered a test protocol used on the rating scale VAS.

\section{Results}

The interventions lasted an average of 157.6 minutes. Recovery times from sensory block was faster in group B (180.2' vs 205') while motor block was faster in group B + B (173.4' vs 169'). In both B and B + B there was a fairly good control of intraoperative hemodynamic and VAS 0 . In the 12 postoperative hours the group B $+B$ showed a VAS of 3, less than group B with VAS 6. Table 1 and Figure 1.

Table 1

\begin{tabular}{cccc}
\hline Group & Average age & Average weight & Mean Time \\
\hline B 9M/12W & 71.24 & $70.24 \mathrm{Kg}$ & $1.66^{\prime}$ \\
& $(\mathrm{DS}+/-14.43)$ & $(\mathrm{DS}+/-7.76)$ & $(\mathrm{DS}+/-0.08)$ \\
$\mathrm{B}+\mathrm{B} 7 \mathrm{M} / 14 \mathrm{~W}$ & 74.81 & $73.05 \mathrm{Kg}$ & $1.66^{\prime}$ \\
& $(\mathrm{DS}+/-16.66)$ & $(\mathrm{DS}+/-10.59)$ & $(\mathrm{DS}+/-0.08)$ \\
\hline
\end{tabular}

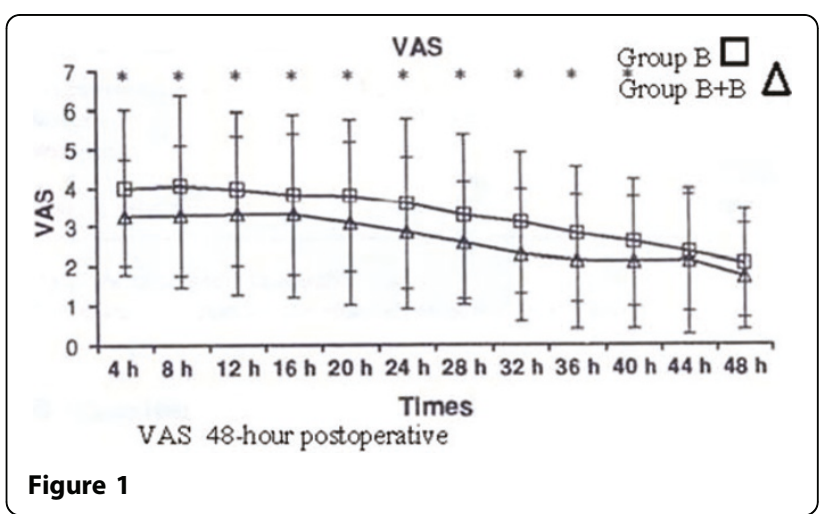

* Correspondence: biagio.lettieri@unina2.it Department of Anaesthesia, Surgical and Emergency Science, Second University of Naples, Italy

(c) 2011 Mattiacci et al; licensee BioMed Central Ltd. This is an open access article distributed under the terms of the Creative Commons Attribution License (http://creativecommons.org/licenses/by/2.0), which permits unrestricted use, distribution, and reproduction in any medium, provided the original work is properly cited. 


\section{Conclusions}

The offset of sensory block was longer for group B + B on the administration of buprenorphine. The use of the subarachnoid technique has proved even more effective with the administration of a mixture of hyperbaric bupivacaine and buprenorphine for postoperative pain control with no obvious impact on intraoperative hemodynamic stability, maintaining the same margin of safety of bupivacaine alone.

Published: 24 August 2011

\section{References}

1. Wahlen BM, Kilian M, Schuster F, Muellenbach R, Roewer N, Kranke P: Patient-controlled versus continuous anesthesiologist-controlled sedation using propofol during regional anesthesia in orthopedic procedures-a pilot study. Expert Opin Pharmacother 2008, 9(16):2733-9.

2. Lane JM: Osteoporosis: a review. Clinical Orthopaedics And Related Research 2004, 426:49-53.

3. Kuusniemi KS, Pihlajamaki KK, Pitkanen MT: A low dose of Hyperbaric bupivacaine for unilateral spinal anesthesia. Reg. Anesth. Pain Med 2000, 25(6):605-10

4. DeHart, vRiley : Nerve injuries in total hip arthroplasty. Am Acad Orthop Surg 1999, 7:101-111

5. Hopkins D, Shipton EA, Potgieter D, Van derMerwe CA, Boon J, De Wet C, Murphy J: Anaesthic Comparison of tramadol and morphine via subcutaneous PCA jollowing major orthopaedic surgery. Can J 1998, 45(5 Pt 1):435-42

\section{Submit your next manuscript to BioMed Central} and take full advantage of:

- Convenient online submission

- Thorough peer review

- No space constraints or color figure charges

- Immediate publication on acceptance

- Inclusion in PubMed, CAS, Scopus and Google Scholar

- Research which is freely available for redistribution

Submit your manuscript at www.biomedcentral.com/submit 